\title{
Perception, motivators and obstacles of biosecurity in cattle production
}

\author{
Perceptie, drijfveren en hindernissen van bioveiligheid in de rundveeproductie
}

\author{
${ }^{1}$ B. Damiaans, ${ }^{1}$ S. Sarrazin, ${ }^{1 *}$ E. Heremans, ${ }^{1} \mathrm{~J}$. Dewulf
}

${ }^{1}$ Veterinary Epidemiology Unit, Department of Reproduction, Obstetrics and Herd Health, Faculty of Veterinary Medicine, Ghent University, Salisburylaan 133, 9820 Merelbeke, Belgium

${ }^{*}$ Currently working in a private poultry veterinary practice

bert.damiaans@UGent.be

\section{$\Lambda_{\text {bstract }}$}

Farm biosecurity includes the prevention of disease transmission within and between farms. Two studies were set up to investigate what motivates and withholds farmers to implement biosecurity measures. The first study aimed to assess the perception of cattle farmers towards biosecurity and to identify possible reasons for its low application. This study consisted of a focus group discussion, of which the trends were used to develop a questionnaire for Flemish cattle farmers. Although the 91 participating farmers were familiar with several measures, they associated them with disease prevention rather than biosecurity. Nearly all farmers $(98 \%)$ identified their herd veterinarian as their main source of information. Twenty percent and $32 \%$ of the respondents were convinced that the implementation of biosecurity would cost them more money and time, respectively. Finally, $80 \%$ of the farmers saw room for improvement of their herd, but indicated a need for practical information. The second study aimed to identify the key elements of twenty preselected biosecurity measures, motivators and obstacles for their implementation. They were judged by twenty-two cattle stakeholders, such as farmers, veterinarians and advisors, on feasibility, efficacy and return on investment. A box for parturition, a plan for rodent control and cleaning and disinfection of the stables scored highest overall. The lowest scoring measures were showering before entering the stables and an animal-free period of 24 hours. Their return on investment scored very low, since high investments are required. For a farmer to understand why biosecurity is beneficial, he must understand all risks and costs of disease and how biosecurity may reduce these risks and costs.

\section{SAMENVATTING}

Bioveiligheid omvat de preventie van ziektetransmissie binnen en tussen bedrijven. Twee aparte studies werden uitgevoerd om te onderzoeken wat veehouders aanzet of tegenhoudt om bioveiligheidsmaatregelen te implementeren. De eerste studie had tot doel de perceptie van rundveehouders rond bioveiligheid in kaart te brengen en de oorzaken voor de lage implementering te identificeren. Het eerste deel van deze studie bestond uit een focusgroepgesprek waarvan de trends gebruikt werden om een vragenlijst te ontwikkelen voor een enquête gericht tot Vlaamse rundveehouders. Hoewel de 91 deelnemende rundveehouders weet hadden van verscheidene bioveiligheidsmaatregelen, associeerden zij deze eerder met ziektepreventie dan met bioveiligheid. De bedrijfsdierenarts lijkt de voornaamste bron van informatie voor de veehouder (98\%). Slechts twintig procent en 32\% van de veehouders zijn ervan overtuigd dat de implementatie van bioveiligheid hen respectievelijk meer geld en tijd zou kosten. Tenslotte ziet $80 \%$ van de veehouders ruimte voor verbetering binnen hun bedrijf en geven ze aan nood te hebben aan praktische informatie. De tweede studie was gericht op de identificatie van hoofdpunten van twintig op voorhand geselecteerde bioveiligheidsmaatregelen, drijfveren en hindernissen aangaande de implementatie ervan. Ze werden door tweeëntwintig professionals uit de rundveesector, zoals veehouders, dierenartsen en adviseurs, beoordeeld op haalbaarheid, efficiëntie en return-on-investment. De afkalfstal, een knaagdierbestrijdingsprogramma en de reiniging en desinfectie van de stallen scoorden het hoogst. De laagst scorende maatregelen waren het douchen vooraleer de stallen te betreden en een 'diervrije' periode van 24 uur. De return-on-investment hiervan was heel laag, omdat daarvoor hoge investeringen noodzakelijk zijn. Om te begrijpen waarom bioveiligheid voordelig is, moet de veehouder een beeld krijgen van alle risico's en kosten van ziekte, en inzien hoe bioveiligheid risico's en kosten kan verminderen. 


\section{INTRODUCTION}

The shift from curative to preventive veterinary medicine involves among others the implementation of biosecurity measures. By definition, biosecurity refers to all measures aiming to prevent pathogens from entering a herd and reducing the spread of pathogens within a herd (Lin et al., 2003; Villarroel et al., 2007; Derks et al., 2013; Laanen et al., 2013). Biosecurity is considered essential for the control of both epidemic (Heffernan et al., 2008) and endemic (Barrington et al., 2002 ; Callan and Garry, 2002) diseases. It is believed that biosecurity can contribute to a better animal health, better animal welfare, higher profits, higher effects of administered vaccines and lower selection for resistance by lower use of antibiotics and anthelmintics (Gunn et al., 2008; Brennan and Christley, 2013; Sarrazin et al., 2014; Nöremark et al., 2016).

However, the actual implementation of biosecurity measures is often low (Ribbens et al., 2008; Nöremark et al., 2010; Van Steenwinkel et al., 2011; Sarrazin et al., 2014). In Belgium, biosecurity measures are better established in pig and poultry production (Ribbens et al., 2008; Van Steenwinkel et al., 2011; Filippitzi et al., 2017), whereas in cattle production, there is much room for improvement of the biosecurity (Sarrazin et al., 2014). In a recent study, it has been shown that few biosecurity measures are undertaken by Belgian cattle farmers, thereby exposing themselves to the risk of disease transmission within and between farms (Sarrazin et al., 2014). Although basic biosecurity measures, such as farm-specific protective clothing and boots, are present in the majority of the farms, they appear to be insufficiently or incorrectly used. These findings raised questions about the reasons behind the limited implementation of biosecurity measures. Lack of information, a higher workload, more time loss or higher investments have been reported in the literature as reasons for this low implementation (Dargatz et al., 2002; Gunn et al., 2008; Brennan and Christley, 2013; Kuster et al., 2015; Nöremark et al., 2016). However, these do not seem applicable to the study of Sarrazin et al. (2014).

Two separate studies were set up to investigate what motivates and withholds farmers to implement biosecurity measures. The aim of the first study, consisting of a qualitative and quantitative part, was to assess the perception of cattle farmers towards the implementation of biosecurity and to identify possible reasons for the low level of application. A second study aimed to identify key elements of known biosecurity measures and the motivators and obstacles for their implementation judged by a range of cattle stakeholders.

\section{MATERIAL AND METHODS}

Study 1: Assessment of the perception of Flemish cattle farmers towards the implementation of biosecurity

This study consisted of a first, qualitative part in the form of a focus group and of a second, quantitative part in the form of a questionnaire based on the results of the first part.

Members of a local farmers association in Flemish Brabant were invited to participate in a focus group session to obtain a homogeneous, "naturally occurring' group of professional cattle farmers, in which both dairy and beef cattle farmers were represented. During the focus group session, their attitude concerning the implementation of biosecurity on cattle farms was discussed, as well as advantages and disadvantages of biosecurity, possible improvements and their opinion on several specific biosecurity measures. The discussion was held in the native tongue of the farmers.

Participants were informed that all recorded data would be processed and analyzed anonymously before the start of the discussion. The discussion was led by a moderator, while another person took notes. The focus group consisted of eight female Flemish cattle farmers and the duration was aimed to be a maximum of two hours according to the guidelines of Kitzinger (1995). First, the participants were asked what they thought farm biosecurity was comprised of. Next, the interviewers explained their definition of farm biosecurity, i.e. the combination of all measures to prevent pathogens from entering a herd and to reduce the spread of pathogens within a herd, and brought eleven statements and open questions about biosecurity into the discussion (Table 1). Each of these were introduced to the participants in a neutral and objective way, with the help of a slide presentation. The participants were asked to express their opinion and talk about personal experiences in order to assess their knowledge about biosecurity, the implementation onfarm of specific measures and the possible difficulties of implementing these measures in practice.

The notes taken during the focus group discussion were anonymized and elaborated afterwards. The results of the focus group discussion were analyzed by summarizing trends across the topics that were discussed and applied to draft the survey for the second part of the study.

Based on the results of the focus group discussion, a questionnaire with five open questions (Table 2) and 18 semi-closed (13 questions with a 5-level Likert scale and five multiple choice questions listed in Table 3) was developed and conducted face-to-face during the fair for Flemish agriculture (Agriflanders) in January 2015. Subjects were randomly chosen and asked to participate anonymously. Only Flemish 
Table 1. Eleven statements and open questions about biosecurity discussed during the focus group session.

1 What is your view on biosecurity and why?

2 Is biosecurity advantageous for the animals/farmer/...? Disadvantages?

3 Which disease present on your farm do you consider the most important?

4 Can biosecurity measures be helpful in handling this disease (less frequent, less severe)?

5 Research has shown that farmers consider keeping a closed farm (no purchase) and testing purchased animals as very important. However, in practice very little attention is devoted to these measures. Why? What is holding them back?

6 Do you quarantine newly purchased animals? And if so, why or why not?

7 On the majority of Belgian cattle farms farm-specific clothes and boots are present for visitors such as veterinarian, cattle salesmen, ... Yet, they are rarely used.

8 One of the most 'forgotten' measures is the working from young animals to old, from healthy to sick.

9 What opportunities do you see to improve biosecurity in practice (in general or specific)? How can cattle farmers be encouraged to improve biosecurity on their own farm?

10 Who should participate in biosecurity on your farm?

11 What reasons do subjects give for not implementing biosecurity measures?

\section{Table 2. Open questions during the survey.}

1 Can you give a short description of the term 'biosecurity'?

2 Can you give a short description of the term 'animal disease prevention'?

3 Is it harder for cattle farmers to implement biosecurity on farm than for pig or poultry farmers (5-level Likert scale)? Why?

4 Describe how you execute quarantine on your farm?

5 Which biosecurity measures could be improved on your farm?

cattle farmers were invited to participate. The questions were limited to consider a time limit of five minutes per interview and the questionnaire was pretested. Responses for the open questions were categorized based on recurrent answers. The results of the questionnaire were analyzed using basic descriptive analysis in Microsoft Excel and the statistical package IBM ${ }^{\circledR}$ SPSS $®$ Statistics 24.

\section{Study 2: workshop with stakeholders in cattle production}

A workshop was organized by the European Innovation Partnership for Agricultural Productivity and Sustainability (EIP-AGRI) in Brussels in January 2015 to identify the key elements of known biosecurity measures and the motivators and obstacles for their implementation. The participants evaluated twenty biosecurity measures by considering for each measure the expected efficacy in disease prevention, the expected feasibility and the expected return on investment (ROI) on a 5-level Likert scale (very low, low, neutral, high, very high) (Table 3). They were first asked to score the measures individually. Afterwards, participants of different backgrounds were asked to discuss their results in small groups.
The results displayed in this article are the individual scores obtained from the participants. The results of the workshop were analyzed using basic descriptive analysis in Microsoft Excel. To each level of the Likert scale, a score was attributed: a score of $-2,-1$, 0,1 and 2 for the levels very low, low, neutral, high and very high, respectively. For each of the twenty measures, the mean score was calculated based on the answers of the twenty respondents to obtain an average score for feasibility, efficacy and ROI. Additionally, an overall score per measure was calculated by making the sum of the respective scores of feasibility, efficacy and ROI. Finally, the measures were ranked based on these scores.

\section{RESULTS}

This paper is written in English while the focus group discussion was conducted in Dutch, the native tongue of the participating farmers. Although all quotes are translated as accurately as possible, nuances may still have gone lost in translation. Therefore, the original Dutch quote is noted after the English translation. 
Study 1: Assessment of the perception of cattle farmers towards the implementation of biosecurity

\section{Focus group discussion}

Four of the participants were dairy farmers, one was a beef farmer and three had both dairy and beef cattle. The discussion lasted for an hour and a half. The results of the discussion are presented below. Statements are mentioned in bold, while pertinent quotes are shown in italics.

\section{Definition of biosecurity and examples}

The participants could not define biosecurity; yet, they were able to associate several aspects to the term, such as avoiding carry-over of diseases, hygiene and no visitors in the stables.

\section{What is your view on biosecurity and why?}

When explaining the definition of biosecurity as used by the investigators, the first reaction of the participants was that the term biosecurity is frightening. Moreover, they assessed the term as misleading, e.g. " "bio'refers to biological agriculture" ("'bio"” doet denken aan biologische landbouw).

Nor did they link the word biosecurity to animal husbandry and felt that the term was not directly interpretable. They felt no involvement with the term and believed it refers to a process that takes place above them. As for the participants, animal disease prevention would be a more appropriate term.

Is biosecurity advantageous for the animals/ farmer/...? Disadvantages?

Nonetheless, with a better understanding of the term, they were convinced that the implementation of biosecurity measures could help in obtaining more healthy animals and consequently, might lower the veterinary costs. However, they seemed more focussed on the disadvantages. As possible disadvantages, the participants first mentioned more administration, for instance the registration of visitors. Secondly, they fear more rules and inspections; thirdly and most important according to the participants, the possible time-consuming aspect.

One of the participants believed it is harder in case of cattle to implement biosecurity than for other species, while another participant, who kept both poultry and cattle, mentioned it to be mainly an adjustment of behavior:

"Actually, it concerns automatic actions we as cattle farmers are not used to. It is mainly a mindset."

"Dat zijn automatismen die we niet gewoon zijn als rundveehouders. Het is een kwestie van instelling."
Which disease do you consider to be the most important on your farm? Can biosecurity measures be helpful in handling this disease (less frequent, less severe)?

Multiple participants stressed the importance of calf diarrhea in the calving period, with many calvings in a short period. In fall and early winter, the biggest fear is bovine respiratory diseases. Also bovine viral diarrhea (BVD) was mentioned. Some farmers had already experienced an outbreak or the presence of carriers despite attempts to eliminate the disease. Scabies is a disease, which is more important for beef cattle farms.

When mentioning the cleaning of boots, the participants asked themselves how far they must go in executing particular biosecurity measures.

"How far should we go? If sick animals are the last to be treated in the morning, are the pathogens of the morning still present on our boots and clothes in the evening? Should we change clothes then?"

"Wat voor nut heeft het als je bijvoorbeeld 's morgens de zieke dieren als laatste behandelt? Zijn de ziektekiemen van 's morgens, 's avonds nog aanwezig op je kleren en laarzen? Moet je dan ook van kleren wisselen?"

"What can you demand of your visitors without nagging?"

"Hoeveel kan je van je bezoekers verlangen zonder vervelend over te komen?"

"Perfectly shielded animals are more sensitive as they have no immunity to any disease."

"Perfect afgeschermde dieren zijn gevoeliger voor ziekte omdat ze geen immuniteit hebben."

"We can hardly leave our clothes outside next to the hutch of a sick calf."

"We kunnen die kledij toch niet buiten laten liggen bij die ene iglo met een ziek kalf?"

The participants argued that a strict separation between sick and healthy animals is practically not feasible; they also mentioned that they do not have physical contact with healthy animals and only treat the sick animals. They considered wearing gloves as an effective and feasible measure.

As a concluding remark, they stressed the need of information about simple biosecurity measures.

Research has shown that farmers consider a closed farm (no purchase) and testing purchased animals very important. Yet, in practice, very little attention is paid to these measures. Why? What is holding them back? 
Although the participants knew and agreed with the principle, they argued that purchase is sometimes necessary. For example, animals need to be bought if there are not enough replacement heifers or in case new genetics need to be introduced on the farm.

Concerning the testing of purchased animals, trust in the purchase protocol of the Flemish animal health service (Diergezondheidszorg Vlaanderen) is high amongst the farmers. However, it is not clear which tests are compulsory. The participants suggested that it would be better to test the purchased animals on the farm of origin in order to avoid infected animals to be entered on a farm.

"There are several packages available, we always take the broadest one. Then you are sure everything has been tested."

"Er zijn verschillende pakketten in de aanbieding. Wij kiezen steeds voor het meest uitgebreide. Dan heb je alles getest."

"Are there many farmers who don't test at purchase?"

"Zijn er nog veel bedrijven waar het aankoopprotocol niet uitgevoerd wordt?"

"Isn't it compulsory to test at purchase?"

"Is het aankoopprotocol niet verplicht?"

Next to ignorance, the cost of the purchase protocol seemed to be the main reason for not testing. Maybe, some farmers do not know that tests at purchase are financially supported.

Do you quarantine newly purchased animals? And if so, why or why not?

Quarantine, defined as a separation of newly purchased animals without possibility of direct contact with own animals, is quickly dismissed with the argument that there is no space available for separation. The question is raised what distance is sufficient.

"If there is no small, separate stable available at that moment, you will not invest in a separate quarantine stable."

"Als er op dat moment door omstandigheden geen klein apart stalletje ter beschikking is, dan ga je ook niet investeren in een aparte quarantainestal."

A quarantine duration of three weeks is considered very long. Especially for dairy cows in lactation, it is considered impossible as they need to go to the milking parlor. All participants realized this is a violation of the quarantine, but minimize the problem:

“... but that's only for a very short period of time. In that time, only little contact is possible and disease can 't possibly be transmitted?"
“... maar dat is maar heel kort. Op zo'n korte tijd is er slechts weinig contact mogelijk en kan ziekte toch niet overgedragen worden?"

Animals returning, e.g. from competitions, are not placed in quarantine. The risks in that case were again minimized, even if the farmer realized that participation in competition is not advisable.

On the majority of Belgian cattle farms, farm specific clothes and boots are present for visitors, such as veterinarian, cattle salesmen, etc. Yet, they are rarely used.

The group is reluctant to ask professional visitors, i.e. herd veterinarians, artificial insemination technicians, cattle salesmen) to use herd specific clothing. As a first reason, the farmers mentioned that since veterinarians have a higher education, they should propose themselves to use herd specific clothing. Secondly, they believed it is hypocritical to demand visitors to use herd specific clothing, while the farmers themselves do not implement specific biosecurity measures, e.g. quarantining cattle returning from a fair.

"But can I really be angry at my vet if he doesn't wear my farm specific boots, if I violate biosecurity principles myself?"

"Kan je commentaar leveren op het feit dat de dierenarts de bedrijfseigen laarzen niet gebruikt als je zelfinbreuken pleegt met betrekking tot bioveiligheid?"

Both herd specific boots and a disinfection bath are compulsory by a quality control label (IKM). However, both are rarely used (correctly) by the farmers adhering to the program. Farmers need to have boots (and clothes) in multiple sizes, and a disinfection bath is considered to lose its effectiveness very quickly.

Herd specific clothes are considered cumbersome to put on and participants understand that visitors do not wish to wear them. For this reason, they prefer an overcoat or coveralls.

They concluded it is not easy for them to execute these measures consistently.

"Our farm lay-out is a hindrance to efficiently use herd specific boots and clothes: there are separate stables and if the stable to visit is too far from the sanitary transition zone, the visitors will not make the effort."

"Onze bedrijfsstructuur staat een efficiënt gebruik van de bedrijfskledij in de weg: er zijn verschillende stallen en als de stal waar de bezoekers verwacht worden te ver van het omkleedlokaal gelegen is, dan doen ze de moeite niet meer."

Another important biosecurity principle is working from young animals to old, from healthy to sick. 
Table 3. Questionnaire results (\%) for 13 semi-closed questions with a 5-level Likert scale (n=91).

\begin{tabular}{|c|c|c|c|c|c|}
\hline \multirow[t]{2}{*}{ Question } & \multicolumn{5}{|c|}{ Likert scale $^{\mathrm{a}}$} \\
\hline & $\begin{array}{c}1 \\
\text { Strongly } \\
\text { disagree }\end{array}$ & 2 & 3 & 4 & $\begin{array}{c}5 \\
\text { Strongly } \\
\text { agree }\end{array}$ \\
\hline I am familiar with the term 'biosecurity' & $8^{\mathrm{b} \%}$ & $34 \%$ & $25 \%$ & $32 \%$ & $1 \%$ \\
\hline I am familiar with the term 'animal disease prevention' & $0 \%$ & $1 \%$ & $8 \%$ & $85 \%$ & $7 \%$ \\
\hline $\begin{array}{l}\text { The term 'biosecurity' is correct term for the concept } \\
\text { (after explanation of the concept) }\end{array}$ & $9 \%$ & $41 \%$ & $11 \%$ & $40 \%$ & $0 \%$ \\
\hline The term 'biosecurity' scares me off & $1 \%$ & $40 \%$ & $15 \%$ & $43 \%$ & $1 \%$ \\
\hline As a farmer I feel responsible for 'biosecurity' & $0 \%$ & $4 \%$ & $9 \%$ & $79 \%$ & $8 \%$ \\
\hline $\begin{array}{l}\text { As a farmer I believe that 'biosecurity' costs me more money } \\
\text { than it raises }\end{array}$ & $1 \%$ & $59 \%$ & $20 \%$ & $18 \%$ & $2 \%$ \\
\hline $\begin{array}{l}\text { As a farmer I believe that 'biosecurity' costs me more time and } \\
\text { effort than it raises }\end{array}$ & $0 \%$ & $52 \%$ & $17 \%$ & $32 \%$ & $0 \%$ \\
\hline I have sufficient information to apply 'biosecurity' well in practice & $1 \%$ & $29 \%$ & $19 \%$ & $51 \%$ & $1 \%$ \\
\hline $\begin{array}{l}\text { I am willing to pay for veterinary advice on 'biosecurity'/'animal } \\
\text { disease prevention' }\end{array}$ & $1 \%$ & $44 \%$ & $28 \%$ & $26 \%$ & $1 \%$ \\
\hline $\begin{array}{l}\text { As a cattle farmer it is more difficult to apply biosecurity well } \\
\text { than as pig/poultry farmer }\end{array}$ & $1 \%$ & $39 \%$ & $13 \%$ & $44 \%$ & $3 \%$ \\
\hline I dare to demand visitors to use herd specific clothing & $0 \%$ & $19 \%$ & $14 \%$ & $60 \%$ & $7 \%$ \\
\hline A quarantine period of 3 weeks cannot be obtained on my farm & $6 \%$ & $22 \%$ & $13 \%$ & $45 \%$ & $13 \%$ \\
\hline I believe that the level of 'biosecurity' can be improved on my farm & $0 \%$ & $8 \%$ & $12 \%$ & $79 \%$ & $1 \%$ \\
\hline
\end{tabular}

${ }^{\mathrm{a}} 1$ = Strongly disagree; $2=$ Disagree; $3=$ Neutral; 4 = Agree; $5=$ Strongly agree

${ }^{b}$ Due to rounding the percentages may not exactly sum up to $100 \%$

The participants realized the importance of this measure and try to work accordingly. However, they raise some practical issues. For instance, they need to milk adult cattle before being able to feed that milk to the calves. Secondly, the farm lay-out is not always arranged appropriately to follow working lines; and last but not least, they believe working lines take more time. Time management and saving time are considered very important.

"We love our job, but don't practice it for fun"

"We doen ons werk graag, maar we doen het niet voor ons plezier."

What opportunities do you see to improve biosecurity in practice (in general or specific)? How can cattle farmers be encouraged to improve biosecurity on their own farm?

When discussing possible ways to improve the implementation of biosecurity in cattle farms, the group stressed the urgent need of additional practical and persistent support and information. This information needs to be practical and should be repeated. How the information is to be spread remains a point of discussion.

The preferred way to obtain this information is through the herd veterinarian. However, the participants remarked that their herd veterinarian has very little time to give preventive advice. Furthermore, they do not expect him/her to be aware of all possible information. They also believe that the herd veterinarian sometimes does not observe certain problems on a farm, as he visits the farm too often. Some participants prefer a more specialized consultant.

"Our veterinarian is able to solve problems, but is not able to prevent them yet."

"Onze dierenarts lost problemen op, maar hij kan ze nog niet voorkomen."

"When trying to solve a farm-specific problem, external advice is appropriate, as the herd veterinarian is blind for some evident problems and does not have the time to deal with them. Herd health management should be an external affair."

"Bij een bedrijfsprobleem is advies van een derde partij aangewezen, want de bedrijfsdierenarts zit er te kort op en is blind voor sommige evidente problemen en heeft er bovendien geen tijd voor. Bedrijfsbegeleiding dient extern te gebeuren."

Furthermore, it is not clear whether there should be paid for veterinary preventive advice. When the 
comparison is made to a doctor's appointment, the participants agreed that it is normal to pay for preventive advice.

"Disease prevention is something you might expect from your herd veterinarian, because he has the knowledge. However, because of the present highpressure structure of the system, it is something you should not expect, because he does not have the time."

"Ziektepreventie is iets wat je van een bedrijfsdierenarts zou kunnen verwachten omdat hij/zij de kennis bezit. Anderzijds mag je van hem/haar geen ziektepreventie in dit veel te druk, huidig systeem verwachten wegens tijdsgebrek.'

\section{Who should participate in biosecurity on your farm?}

The answer to this question was exceedingly clear: all visitors who have contact with the animals, should participate in biosecurity on the farm. Unexpected visitors, especially those with high education, can cause irritation when they do not take the available measures.

\section{What arguments do visitors cite when they do not want to participate?}

Some visitors do not believe in the usefulness of certain measures or believe it to be redundant as the farmer does not keep to all principles of biosecurity himself. Lack of time is also a frequently cited reason. Moreover, although they are not unwilling to participate, it is hard to habituate oneself to the measures. Other cited reasons were the absence of the correct size or brand of boots and clothing.

\section{Questionnaire results}

Ninety-one face-to-face interviews (25\% dairy farmers, $43 \%$ beef and $32 \%$ mixed) were conducted (Table 3). All respondents originated from Flanders and the majority were male $(88 \%)$.

Although the Flemish cattle farmers were familiar with several specific biosecurity measures, such as quarantine and the use of herd-specific clothing, they did not associate these measures with the term biosecurity. They tended to relate the term biosecurity to food safety $(23.0 \%)$ and ecological farming $(21.0 \%)$ or they had no idea what this concept meant (48.0\%). Only $5.5 \%$ of the definitions provided by the participants could be considered correct. The farmers seemed to be more familiar with the term 'animal disease prevention' as they mentioned prevention of disease, control of BVD, IBR, neosporosis and other diseases and vaccination when defining this term. However, two of the participating farmers described disease prevention as the use of antibiotics. The type of farm did not seem to have influence on the knowledge of these terms.
Out of 38 participants who claimed not to be familiar with the term 'biosecurity', $65.8 \%$ followed working lines, $31.6 \%$ did not purchase cattle and 55.3\% quarantines purchased animals (yet, only $40.4 \%$ had a separate quarantine stable and $28.4 \%$ of the farmers thought a quarantine period of three weeks is feasible). This shows that farmers indeed have more knowledge of separate biosecurity measures than of the term 'biosecurity' itself.

The majority of the farmers $(87.0 \%)$ felt responsible for the implementation of biosecurity on their farm, and $52.0 \%$ of the respondents indicated to dispose of sufficient information to implement biosecurity adequately. Nearly all farmers (98.0\%) identified their herd veterinarian as the main source of this information.

However, only $45.0 \%$ of the farmers is willing to pay their herd veterinarian for preventive advice. Forty-seven percent believed that it is more difficult to implement biosecurity for cattle farmers than for pig and poultry farmers, since cattle are pastured $(30.0 \%)$ and cattle farms are more often visited (13.0\%). Whether or not willing to pay for advice differed according to the preferred source of information: $100 \%$ of the participants who preferred an external source in combination with their herd veterinarian is willing to pay for advice, whereas only $23.6 \%$ of those expecting advice from the herd veterinarian only, is willing to pay.

Nonetheless, $80.0 \%$ and $78.0 \%$ of the respondents were convinced that the implementation of biosecurity would not cost them money nor require more time and effort, respectively. Of all the farmers, 80.0\% saw room for improvement of the biosecurity level in their herd. Proposed biosecurity measures are quarantining purchased cattle, disinfection and herd specific clothing. However, $13.0 \%$ of these farmers first wanted to gain information before answering the question and $19.5 \%$ had no idea what to improve.

\section{Results EIP-AGRI workshop}

Twenty-two participants involved in cattle production, including farmers or their representatives, researchers, farmer advisors, practicing veterinarians, animal health services, representatives of trade, industry, government or EU from twelve European countries attended the workshop.

Scoring highest for the overall score is the presence and use of a separate box for parturition on the farm (Table 4 and Figure 1). In the second rank for the combined score, a systematic plan for rodent control can be found. A proper cleaning and disinfection of the stables are ranked third.

Using a separate box for parturition also returns in the single score for efficacy in the first rank. Proper cleaning and disinfection of the stables after each production round were considered very efficient (second rank), yet less feasible (shared sixth rank). Similarly, 
Table 4. Ranking of perceived efficacy, feasibility, return on investment and an overall score for 20 biosecurity measures (for cattle). A ranking is provided for each measure and presented in bold for the top 5. A measure with score ' 1 ' was judged the highest, a measure with score ' 20 ' was judged lowest.

\section{Biosecurity measure}

Ranking

A separate and dedicated box for parturition is available and used only for this purpose
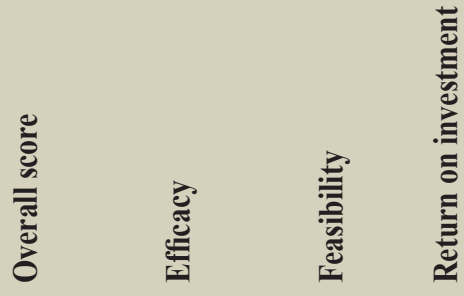

A systematic plan for rodent control is installed

Proper cleaning and disinfection of the stables

2
3

All vehicles for animal transport are empty and cleaned and disinfected before entering

the premises

No contact with animals from other farmers is possible through pasture contact

5

Dead animals are stored at a specific designated location away from the stables

All used equipment is stable specific

If animals are bought they are always kept in a quarantine stable for at least 4 weeks

Disposable or herd specific clothing and footwear required before entering the stables

Hygiene lock (specific designated changing and hygiene room for persons) available

before entering the stable

Different age groups are strictly separated in different compartments

1

3

1

If animals are bought, they always come from the same supplier

Chemical and microbiological analysis of drinking water (at the source and the end 13 $\mathrm{f}$ the drinking line) at least once a year

No pets allowed in the stables

Employees are not allowed to work on other cattle farms

A systematic plan for insect control is installed

Strict working lines (starting with the youngest animals and working towards the oldest animals) are used

Clear separation of the farmyard in a dirty and clean (no access for vehicles, persons or animals from outside the herd) area

A minimum "animal-free" period of 24 hours before entrance to the stables is allowed 


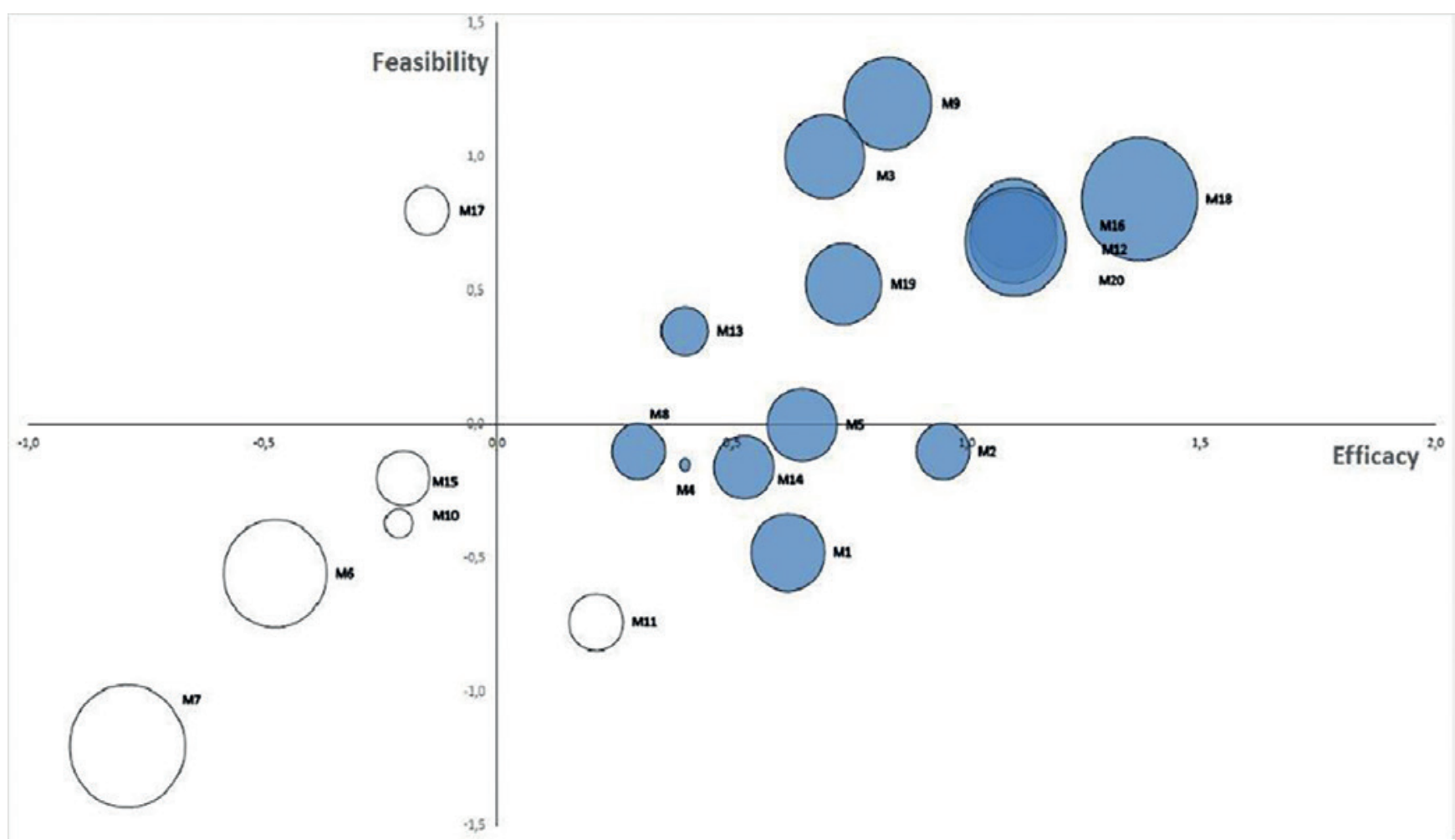

Figure 1. Visual representation of the average scores of the biosecurity measures for estimated efficacy (x-axis), feasibility (yaxis) and return on investment (bullets) based on a 5-level likert scale (-2: very low, -1: low, 0: neutral, 1: high, 2: very high). Return on investment is represented by the color and size of the bullets: a blue bullet denotes a positive value for return on investment, while a white bullet denotes a negative value for return on investment. A larger bullet size denotes a higher absolute value for return on investment.

Measure

M1 If animals are bought they always come from the same supplier

M2 If animals are bought they are always kept in a quarantine barn for at least 4 weeks

M3 Dead animals are stored at a specific designated location away from the barns

M4 Hygiene lock (specific designated changing and hygiene room for visitors) available before entering the barn

M5 Disposable or herd-specific clothing and footwear required before entering the barns

M6 A minimum animal-free period of 24 hours is required before entrance of any visitors to the barns

M7 Showering required before entrance to the barns

M8 No pets allowed in the barns

M9 Systematic plan for rodent control is installed

M10 Systematic plan for insect control is installed

M11 Clear separation of the farmyard in a dirty and clean

mandatory cleaning and disinfection of vehicles before entering the premises of the farm are ranked third for efficacy.

A rodent control plan was judged the most feasible of all biosecurity measures. A carcass storage away from the stables scores the second rank for feasibility, but has a lower score for efficacy (shared seventh). In the third rank, a separate box for parturition returns.

ROI seems to be judged similarly to efficacy and feasibility as the two highest judged measures for ef- (no access for vehicles, persons or animals from outside the herd) area.

M12 All vehicles for animal transport are empty, cleaned and disinfected before entering the premises

M13 No employees who are also working on other cattle farms

M14 Different age groups are strictly separated in different compartments

M15 Strict working lines (starting with the youngest animals and working towards the oldest animals) are used

M16 Contact with animals from other farmers is not possible through pasture

M17 Chemical and microbiological analysis of drinking water (at the source and the end of the drinking line) at least once a year

M18 A separate and dedicated box for parturition is available and used

M19 All used equipment is holding specific

M20 Proper cleaning and disinfection of the barns after every production round

ficacy score the same ranks in ROI (a separate box for parturition first, cleaning and disinfection after each production round second). Third highest for ROI is the biosecurity measure considered most feasible, a rodent control plan.

The common lowest scoring measure is a required shower before entering the stables. This measure scored rank twenty in all categories. The measure considered to be second lowest (rank eighteen for feasibility and rank nineteen in the other categories) is 
the obligation of an 'animal-free' period of at least 24 hours before access to the stables is allowed. Their ROI is lowest of all, since high investments may be required to implement them.

\section{DISCUSSION}

In this paper, the results of two studies concerning the perception of biosecurity and biosecurity measures by cattle farmers and stakeholders are described. Both studies show that their knowledge of biosecurity principles can still be improved. The participants in both studies displayed a positive attitude towards biosecurity, but not necessarily a positive view on all biosecurity measures. In the first study, qualitative (focus group) and quantitative (questionnaire) research was combined to describe a possible thresholds for a good implementation of biosecurity measures in cattle farms from a farmers' point of view. Quantitative research is frequently used in veterinary medicine, while qualitative research is often criticized for not having enough scientific rigor (Krefting, 1990). Although in qualitative research, the participants are not assumed to be representative for the population, the obtained results can be useful to better understand the subject (Christley and Perkins, 2010). By using a combination of both types of research, the study has a higher validity and reliability. Qualitative research provides accurate, yet broad information, raising the validity of the research. When quantified, the more important elements can be identified, improving reliability. All participating farmers in the focus group discussion were female, which might create a misrepresentation of the results as most recorded farmers seem to be male ( $88 \%$ during the survey). However, most farms in Belgium are family businesses where the partners contribute equally to the farm. This was the case for the members of the focus group discussion. Results from the focus group discussion and the survey both converge and diverge on certain subjects; yet, it is not clear whether this is caused by the gender distribution of the participants or not. Many other differences, such as differences in posing questions or more specific questions are possible causes.

For an overall evaluation of biosecurity measures, as a sample of convenience during the EIP-AGRI days, the sample size of the present workshop was too small to draw conclusions on the application of biosecurity measures in the represented European countries. Nevertheless, the present evaluation may again serve as an indication of why or why not farmers are motivated to implement certain biosecurity measures. Moreover, it must be taken into account that the participants of this survey were not exclusively farmers; hence, the results of this study cannot be used to represent the farmers' opinion. The three criteria judged during this study were chosen as farmers seemed to consider them as crucial before implementing bio- security measures. Feasibility was considered to have influence on the farmers' motivation as some measures were perceived impractical or impossible (Garforth et al., 2013). If farmers do not believe a measure to be important (efficient) or to have a positive ROI, they might not implement it. Unfortunately, evidence is often lacking (Alarcon et al., 2014).

During the first study, the participants found the term biosecurity frightening and did not feel involved with it as they thought biosecurity to be discussed on a higher level, i.e. governmental level. Participants were very familiar with the term disease prevention. If biosecurity would be introduced as part of disease prevention, perhaps farmers would be less suspicious and more receptive to the term.

Yet, those not comfortable with the term biosecurity in both parts of the study, had already implemented various biosecurity measures without knowing the measures concerned biosecurity. Hence, although they did not seem familiar with the term itself, they seemed to be familiar with some principles of biosecurity used and ranked during the second study.

The presence of a maternity pen was most highly judged of all measures and was also considered important by the participants of the first study. Although a maternity pen is often incorrectly used or not present (Sarrazin et al., 2014), in the literature, the maternity pen has been shown to be a highly profitable measure. Mee (1991) described a decrease of calf mortality rate and Curtis et al. (1988) observed a reduction in the occurrence of calf diarrhea when calves were born in a maternity pen. It has often been reported as important in avoiding perinatal calf mortality, morbidity (Svensson et al., 2003; Mee, 2004; Mee, 2008) or infection with several calf diseases (salmonellosis, cryptosporidiosis, respiratory diseases) (Garber et al., 1994; Svensson et al., 2003; Fossler et al., 2005a; Fossler et al., 2005b).

The importance of a rodent control program was mentioned during the first study, as the role of rodents as vectors and carriers of leptospirosis (Endepols et al., 2003; Sarrazin et al., 2017), salmonellosis (Tablante Jr and Lane, 1989; Warnick et al., 2001; Sarrazin et al., 2017) and other diseases (Endepols et al., 2003; Sarrazin et al., 2017) has been clearly proven. However, this measure was judged feasible and less efficient, possibly because farmers do not always consider a rodent infestation as a problem (Leirs et al., 2004); they use a subjective threshold to implement a rodent control program (e.g. visible confirmation of the infestation) (Endepols et al., 2003; Meerburg and Kijlstra, 2007) or do not execute the implemented plan properly (Endepols et al., 2003). The participants of the second survey were aware of the diseases rodents may transmit as a rodent control program scored high in all criteria. An insect control program on the other hand was ranked amongst the lowest of biosecurity measures, nor was it stressed during the first study. This may be considered strange as, next to skin 
damages and irritations insects may cause, they may transmit multiple diseases, such as summer mastitis (Bramley et al., 1985), moraxellosis (Postma et al., 2008), besnoïtosis (Gutiérrez Expósito et al., 2017) and vector borne diseases like bluetongue (Tatem et al., 2003), lumpy skin disease (Tuppurainen and Oura, 2012) and Schmallenberg disease (Garigliany et al., 2012).

The two lowest scored measures, i. e. showering and an animal-free period, have been hardly reported in the literature concerning cattle biosecurity. Even in pig production, where biosecurity is more established, the level of implementation of these measures is low (Ribbens et al., 2008). The problem of time and investment may be raised as an obstacle for the implementation of these two measures. Additionally, it should be taken into account that farmers may not like to ask visitors to take a shower as it might be regarded as an invasion of privacy. Moreover, many other measures must be executed before showering can be of any use. If visitors do not pass a hygiene lock or do not wear herd specific boots and clothing, a shower is redundant. As for the animal-free period, it is for instance not realistic to expect a veterinarian to only visit one farm a day. These measures (showering and an animal-free period) were not mentioned during the first study. Perhaps, they were not regarded as biosecurity measures or were considered too difficult to implement.

Participants of both parts of the first study were convinced that the application of biosecurity measures has advantages, which is in agreement with the research of Laanen et al. (2014). They generally situated these advantages in the improvement of herd health, which would benefit them financially. Such a positive opinion on a biosecurity measure correlates positively with the implementation of that measure (Valeeva et al., 2011). However, during the second study, five out of twenty biosecurity measures scored low (less than 0 on average on a Likert scale of -2 to +2 ) for all criteria judged (Figure 1). In both the focus group and in the survey, the disadvantages were emphasized. Members of the focus group discussion mentioned time and labor as disadvantages, while only half (48\%) of the participants of the survey agreed with them. In the survey of Brennan en Christley (2013), similar results were found, while in the study of Laanen et al. (2014) and Jansen et al. (2010a) lack of time was the lowest judged reason for not using biosecurity tools. However, it can be questioned whether implementing biosecurity indeed takes more time or if it is only perceived as such. After all, many biosecurity measures include a structured, repetitive method, which is expected to gain time. Changing the modus operandi seems to be the challenge (Kristensen and Jakobsen, 2011), as farmers are inclined to carry on in the way they are used to (Casal et al., 2007).

The participants of the focus group indicated the need for more information in a simple, practical manner. This finding is in agreement with earlier research, which state insufficient, confusing or lack of herd-specific information as obstacles to implement biosecurity (Toma et al., 2013; Laanen et al., 2014; Sayers et al., 2014). The farmers of the present and other studies consider their herd veterinarian as the most reliable source of information on biosecurity (Brennan and Christley, 2013; Garforth et al., 2013). The veterinarian is the key actor to help farmers understand the logical reasoning behind proposed biosecurity measures, because the farmers know him/her and trust in his/her advice and capability (Racicot et al., 2012; Alarcon et al., 2014; Laanen et al., 2014).

During the first study, many possible reasons were mentioned, which could explain the line of thought of the participants of the second study. In the second study, the measure of keeping a closed farm (no purchase) could have been added; yet, it was chosen to assess two measures closely related, i.e. quarantine and same supplier. The farmers in the first study found it to be a measure of high importance but believed it to be hardly feasible. In addition, they mentioned quarantining purchased animals and found it to be an efficient measure. However, they believed a quarantine period of three weeks and fully physical separation hard to achieve. Their opinion concurs with the opinion of the participants of the second study, as they rated quarantine fairly efficient (fifth) but gave a lower score for feasibility (twelfth). The score for ROI (eleventh) was comparative to feasibility. Farmers of the first survey indeed questioned the cost of a stable that is used only a few times a year even if they agreed it has benefits. Buying animals from only one supplier was not thought of during the first survey.

The idea of herd-specific boots and clothing was not well-received in both studies. During the second study, the scores were in the middle of the ranking (ninth and tenth ranks) showing similarities to the results of the first study. Farmers in the first study were reluctant to ask visitors to wear herd-specific boots and clothing and claimed the visitors themselves were reluctant as well. They found the measure cumbersome and hard to execute consistently, as there are for example multiple entrances to the farm, even though all facilities were present. Perhaps the measure would have been judged more efficient in the second study, if practical problems concerning the proper execution would be solved. For example: a simple hygiene lock located at a critical juncture where all visitors should pass, could solve the issue of having multiple entrances. However, in the second study, a measure pertaining to this was judged even less feasible.

To understand why implementing biosecurity measures is beneficial, the farmer must first understand the risk of introduction and harm caused by both epidemic and endemic diseases. Evidence of the economic benefit of biosecurity measures is limited as quantitative data on costs and benefits are lacking. 
In this respect, farmers may be reluctant to invest in biosecurity. In addition, cattle farmers are often not aware of the cost, neither of the loss of income caused by disease, which is even higher (Laanen et al., 2014). If farmers would be well-informed on both issues, they would be more willing to improve biosecurity on their farm.

Secondly, to obtain better results, a farmer should understand the rationale behind a biosecurity measure, as it is easier to exert and sustain a change in behavior if it is clear why that change has to be made (Wells et al., 2002). Other methods to influence the farmer's behavior are for instance the campaign described by Jansen et al. (2010b), in which a simple message conveyed with humor and free samples was meant to convince farmers to use milking gloves. However, it would be useful to understand the motivation and reasons behind the behavior of farmers, in which the second study of this paper might be of assistance. After all, it would be hard to convince farmers to change their behavior if they themselves were not convinced or had no intention to change (Kristensen and Enevoldsen, 2008; Brennan and Christley, 2013).

Therefore, in analogy with the pig and poultry sectors, cattle farmers could be provided with accessible and practical information through a biosecurity testing tool, which explains the concept of biosecurity and increases their awareness (www.BioCheck. UGent.be; (Laanen et al., 2010; Gelaude et al., 2014). It may also be useful to list the mechanisms of direct and indirect spread of disease, so farmers may gain insight into the effectiveness of biosecurity measures (Nöremark and Sternberg-Lewerin, 2014). Secondly, a preventive strategy could be developed in collaboration with the herd veterinarian who knows the herd structure and may inform on the critical points for that specific farm (Villarroel et al., 2007; Ellis-Iversen et al., 2010; Brennan and Christley, 2013; Garforth et al., 2013). The ultimate goal should be to consider biosecurity as a collective responsibility with farmers taking initiative to improve their biosecurity level and herd veterinarians as coaches, rather than an individual responsibility (Postma et al., 2017). Thirdly, to be able to influence the farmers' behavior, it must be understood first. It would be useful to understand motivational and behavioral factors of the farmers in deciding on issues related to biosecurity (Kristensen and Enevoldsen, 2008).

\section{ACKNOWLEDGEMENTS}

The authors wish to thank Diergezondheidszorg Vlaanderen (DGZ) for the possibility to question the farmers during the fair for Flemish agriculture (Agrianders) and the cattle farmers for participating in the study.

\section{REFERENCES}

Alarcon P., Wieland B., Mateus A.L., Dewberry C. (2014). Pig farmers' perceptions, attitudes, influences and management of information in the decision-making process for disease control. Preventive Veterinary Medicine 116, 223-242.

Barrington G.M., Gay J.M., Evermann J.F. (2002). Biosecurity for neonatal gastrointestinal diseases. Veterinary Clinics of North America: Food Animal Practice 18, 7-34.

Bramley A., Hillerton J., Higgs T., Hogben E. (1985). The carriage of summer mastitis pathogens by muscid flies. British Veterinary Journal 141, 618-627.

Brennan M.L., Christley R.M. (2013). Cattle producers' perceptions of biosecurity. BMC Veterinary Research 9, 71.

Callan R.J., Garry F.B. (2002). Biosecurity and bovine respiratory disease. Veterinary Clinics of North America: Food Animal Practice 18, 57-77.

Casal J., De Manuel A., Mateu E., Martin M. (2007). Biosecurity measures on swine farms in Spain: perceptions by farmers and their relationship to current on-farm measures. Preventive Veterinary Medicine 82, 138-150.

Christley R., Perkins E. (2010). Researching hard to reach areas of knowledge: qualitative research in veterinary science. Equine Veterinary Journal 42, 285-286.

Curtis C.R., Erb H.N., White M.E. (1988). Descriptive epidemiology of calfhood morbidity and mortality in New York Holstein herds. Preventive Veterinary Medicine 5, 293-307.

Dargatz D.A., Garry F.B., Traub-Dargatz J.L. (2002). An introduction to biosecurity of cattle operations. Veterinary Clinics of North America: Food Animal Practice 18, 1-205.

Derks M., Van Werven T., Hogeveen H., Kremer W. (2013). Veterinary herd health management programs on dairy farms in the Netherlands: use, execution, and relations to farmer characteristics. Journal of Dairy Science 96, 1623-1637.

Ellis-Iversen J., Cook A.J., Watson E., Nielen M., Larkin L., Wooldridge M., Hogeveen H. (2010). Perceptions, circumstances and motivators that influence implementation of zoonotic control programs on cattle farms. Preventive Veterinary Medicine 93, 276-285.

Endepols S., Klemann N., Pelz H.-J., Ziebell K.-L. (2003). A scheme for the placement of rodenticide baits for rat eradication on confinement livestock farms. Preventive Veterinary Medicine 58, 115-123.

Filippitzi M.E., Goumperis T., Robinson T., Saegerman C. (2017). Microbiological Zoonotic Emerging Risks, Transmitted Between Livestock Animals and Humans (2007-2015). Transboundary and Emerging Diseases 64, 1059-1070.

Fossler C.P., Wells S.J., Kaneene J.B., Ruegg P.L., Warnick L.D., Bender J.B., Eberly L.E., Godden S.M., Halbert L.W. (2005a). Herd-level factors associated with isolation of Salmonella in a multi-state study of conventional and organic dairy farms I. Salmonella shedding in cows. Preventive Veterinary Medicine 70, 257-77.

Fossler C.P., Wells S.J., Kaneene J.B., Ruegg P.L., Warnick L.D., Bender J.B., Eberly L.E., Godden S.M., Halbert L.W. (2005b). Herd-level factors associated with isolation of Salmonella in a multi-state study of convention- 
al and organic dairy farms. II. Salmonella shedding in calves. Preventive Veterinary Medicine 70, 279-291.

Garber L., Salman M., Hurd H., Keefe T., Schlater J. (1994). Potential risk factors for Cryptosporidium infection in dairy calves. Journal of the American Veterinary Medical Association 205, 86-86.

Garforth C.J., Bailey A.P., Tranter R.B. (2013). Farmers' attitudes to disease risk management in England: a comparative analysis of sheep and pig farmers. Preventive Veterinary Medicine 110, 456-466.

Garigliany M.-M., Bayrou C., Kleijnen D., Cassart D., Desmecht D. (2012). Schmallenberg virus in domestic cattle, Belgium, 2012. Emerging Infectious Diseases 18, 1512.

Gelaude P., Schlepers M., Verlinden M., Laanen M., Dewulf J. (2014). Biocheck. UGent: A quantitative tool to measure biosecurity at broiler farms and the relationship with technical performances and antimicrobial use. Poultry Science 93, 2740-2751.

Gunn G., Heffernan C., Hall M., McLeod A., Hovi M. (2008). Measuring and comparing constraints to improved biosecurity amongst GB farmers, veterinarians and the auxiliary industries. Preventive Veterinary Medicine 84, 310-323.

Gutiérrez Expósito D., Ortega Mora L., García Lunar P., Rojo Montejo S., Zabala J., Serrano M., Alvarez García G. (2017). Clinical and serological dynamics of Besnoitia besnoiti infection in three endemically infected beef cattle herds. Transboundary and Emerging Diseases 64, 538-546.

Heffernan C., Nielsen L., Thomson K., Gunn G. (2008). An exploration of the drivers to bio-security collective action among a sample of UK cattle and sheep farmers. Preventive Veterinary Medicine 87, 358-372.

Jansen J., Steuten C., Renes R., Aarts N., Lam T. (2010a). Debunking the myth of the hard-to-reach farmer: Effective communication on udder health. Journal of Dairy Science 93, 1296-1306.

Jansen J., Van Schaik G., Renes R., Lam T. (2010b). The effect of a national mastitis control program on the attitudes, knowledge, and behavior of farmers in the Netherlands. Journal of Dairy Science 93, 5737-5747.

Kitzinger J. (1995). Qualitative research. Introducing focus groups. British Medical Journal 311, 299.

Krefting L. (1990). Rigor in qualitative research: The assessment of trustworthiness. American Journal of Occupational Therapy 45 (3), 214-222.

Kristensen E., Enevoldsen C. (2008). A mixed methods inquiry: How dairy farmers perceive the value (s) of their involvement in an intensive dairy herd health management program. Acta Veterinaria Scandinavica 50, 50.

Kristensen E., Jakobsen E.B. (2011). Danish dairy farmers' perception of biosecurity. Preventive Veterinary Medicine 99, 122-129.

Kuster K., Cousin M.-E., Jemmi T., Schüpbach-Regula G., Magouras I. (2015). Expert opinion on the perceived effectiveness and importance of on-farm biosecurity measures for cattle and swine farms in Switzerland. PloS One 10, e0144533.

Laanen M., Beek J., Ribbens S., Vangroenweghe F., Maes D., Dewulf J. (2010). Biosecurity on pig herds: Development of an on-line scoring system and the results of the first 99 participating herds. Vlaams Diergeneeskundig Tijdschrift 79, 302-306.

Laanen M., Maes D., Hendriksen C., Gelaude P., De Vlieg- her S., Rosseel Y., Dewulf J. (2014). Pig, cattle and poultry farmers with a known interest in research have comparable perspectives on disease prevention and on-farm biosecurity. Preventive Veterinary Medicine 115, 1-9.

Laanen M., Persoons D., Ribbens S., de Jong E., Callens B., Strubbe M., Maes D., Dewulf J. (2013). Relationship between biosecurity and production/antimicrobial treatment characteristics in pig herds. The Veterinary Journal 198, 508-512.

Leirs H., Lodal J., Knorr M. (2004). Factors correlated with the presence of rodents on outdoor pig farms in Denmark and suggestions for management strategies. NJAS-Wageningen Journal of Life Sciences 52, 145-161.

Lin J., Kaphle K., Wu L., Yang N., Lu G., Yu C., Yamada H., Rogers P. (2003). Sustainable veterinary medicine for the new era. Revue Scientifique et Technique-Office International des Epizooties 22, 949-964.

Mee J. (1991). Factors affecting the spontaneous twinning rate and the effect of twinning on calving problems in 9 Irish dairy herds. Irish Veterinary Journal 44, 14-20.

Mee J.F. (2004). Managing the dairy cow at calving time. Veterinary Clinics: Food Animal Practice 20, 521-546.

Mee J.F. (2008). Newborn dairy calf management. Veterinary Clinics of North America: Food Animal Practice 24, 1-17.

Meerburg B.G., Kijlstra A. (2007). Role of rodents in transmission of Salmonella and Campylobacter. Journal of the Science of Food and Agriculture 87, 2774-2781.

Nöremark M., Frössling J., Lewerin S.S. (2010). Application of routines that contribute to on farm biosecurity as reported by swedish livestock farmers. Transboundary and Emerging Diseases 57, 225-236.

Nöremark M., Sternberg-Lewerin S. (2014). On-farm biosecurity as perceived by professionals visiting Swedish farms. Acta Veterinaria Scandinavica 56, 28.

Nöremark M., Sternberg Lewerin S., Ernholm L., Frössling J. (2016). Swedish farmers' opinions about biosecurity and their intention to make professionals use clean protective clothing when entering the stable. Frontiers in Veterinary Science 3, 46.

Postma G.C., Carfagnini J.C., Minatel L. (2008). Moraxella bovis pathogenicity: an update. Comparative Immunology, Microbiology and Infectious Diseases 31, 449-458.

Postma M., Vanderhaeghen W., Sarrazin S., Maes D., Dewulf J. (2017). Reducing antimicrobial usage in pig production without jeopardizing production parameters. Zoonoses and Public Health 64, 63-74.

Racicot M., Venne D., Durivage A., Vaillancourt J.-P. (2012). Evaluation of strategies to enhance biosecurity compliance on poultry farms in Quebec: effect of audits and cameras. Preventive Veterinary Medicine 103, 208218.

Ribbens S., Dewulf J., Koenen F., Mintiens K., De Sadeleer L., de Kruif A., Maes D. (2008). A survey on biosecurity and management practices in Belgian pig herds. Preventive Veterinary Medicine 83, 228-241.

Sarrazin S., Cay A.B., Laureyns J., Dewulf J. (2014). A survey on biosecurity and management practices in selected Belgian cattle farms. Preventive Veterinary Medicine 117, 129-139.

Sarrazin S., Damiaans B., Renault V. (2017). Transmission of cattle diseases and biosecurity in cattle. In: Van Immerseel Filip, Dewulf J. (editors). Biosecurity in Animal Production and Veterinary Medicine. Acco, Ghent, Belgium, 375-408. 
Sayers R., Good M., Sayers G. (2014). A survey of biosecurity-related practices, opinions and communications across dairy farm veterinarians and advisors. The Veterinary Journal 200, 261-269.

Svensson C., Lundborg K., Emanuelson U., Olsson S.-O. (2003). Morbidity in Swedish dairy calves from birth to 90 days of age and individual calf-level risk factors for infectious diseases. Preventive Veterinary Medicine 58, 179-197.

Tablante Jr N.L., Lane V.M. (1989). Wild mice as potential reservoirs of Salmonella dublin in a closed dairy herd. The Canadian Veterinary Journal 30, 590.

Tatem A., Baylis M., Mellor P., Purse B., Capela R., Pena I., Rogers D. (2003). Prediction of bluetongue vector distribution in Europe and north Africa using satellite imagery. Veterinary Microbiology 97, 13-29.

Toma L., Stott A.W., Heffernan C., Ringrose S., Gunn G.J. (2013). Determinants of biosecurity behaviour of British cattle and sheep farmers - A behavioural economics analysis. Preventive Veterinary Medicine 108, 321-333.

Tuppurainen E., Oura C.A. (2012). Lumpy skin disease: an emerging threat to Europe, the Middle East and Asia. Transboundary and Emerging Diseases 59, 40-48.
Valeeva N., van Asseldonk M., Backus G. (2011). Perceived risk and strategy efficacy as motivators of risk management strategy adoption to prevent animal diseases in pig farming. Preventive Veterinary Medicine 102, 284-295.

Van Steenwinkel S., Ribbens S., Ducheyne E., Goossens E., Dewulf J. (2011). Assessing biosecurity practices, movements and densities of poultry sites across Belgium, resulting in different farm risk-groups for infectious disease introduction and spread. Preventive Veterinary Medicine 98, 259-270.

Villarroel A., Dargatz D.A., Lane V.M., McCluskey B.J., Salman M.D. (2007). Suggested outline of potential critical control points for biosecurity and biocontainment on large dairy farms. Journal of the American Veterinary Medical Association 230, 808-819.

Warnick L.D., Crofton L.M., Pelzer K.D., Hawkins M. (2001). Risk factors for clinical salmonellosis in Virginia, USA cattle herds. Preventive Veterinary Medicine 49, 259-275.

Wells S.J., Dee S., Godden S. (2002). Biosecurity for gastrointestinal diseases of adult dairy cattle. Veterinary Clinics of North America: Food Animal Practice 18, 35-55.

\section{ONGELIJKHEID BEGINT BIJ DE TREKOS EN HET PAARD}

Ongelijkheid begon in de prehistorische samenlevingen met de beschikbaarheid van paarden en andere trek- en lastdieren. Die konden ploegen en karren trekken. Ze leverden bovendien mest, waardoor de opbrengst van de landbouwgronden aanzienlijk kon verhogen. Vlees, melk en huiden waren ook aardig meegenomen. Rij- en lastdieren maakten handel over grote afstand mogelijk, denk maar aan de Zijderoute. Handel is de beste manier om rijkdom te vergaren. Maar paarden (en kamelen) waren ook krachtige offensieve wapens. Zo ontstond er een bereden elite. Die kon in minder dan geen tijd grote gebieden veroveren. Denk aan de Hunnen en Djengis Khan. 'Ridder' betekent niet toevallig ruiter. En waarom de adel in Frankrijk zich liet aanspreken met 'chevalier' is al even duidelijk. Te paard kon je bovendien veroveringstochten organiseren die verder reikten dan het naburige dorp. In het prehistorische Amerika was de ongelijkheid minder groot dan in Eurazië. Daar had je paarden noch runderen. Inca's en aanverwante volkeren hadden geen karren of wagens. Ze beschikten immers niet over geschikte trekdieren.

Naar: Pieter van Dooren (2017), Ongelijkheid begint bij het paard. In: de Standaard, 16 nov. Gebaseerd op Kohler, T. et al. (2017). Greater post-Neolytic wealth disparities in Eurasia than in North America and Mesoamerica. Nature 16 november. 


\section{Bioveiligheid \\ bij Vlaamse rundveehouders}

Eyelien Heremans

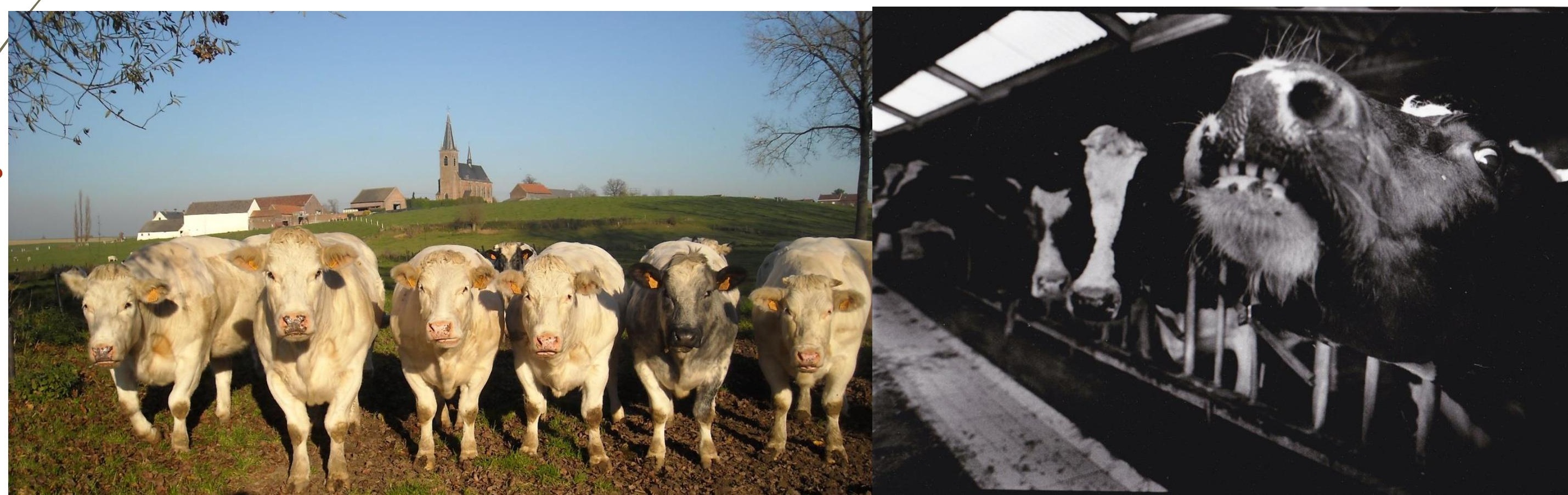




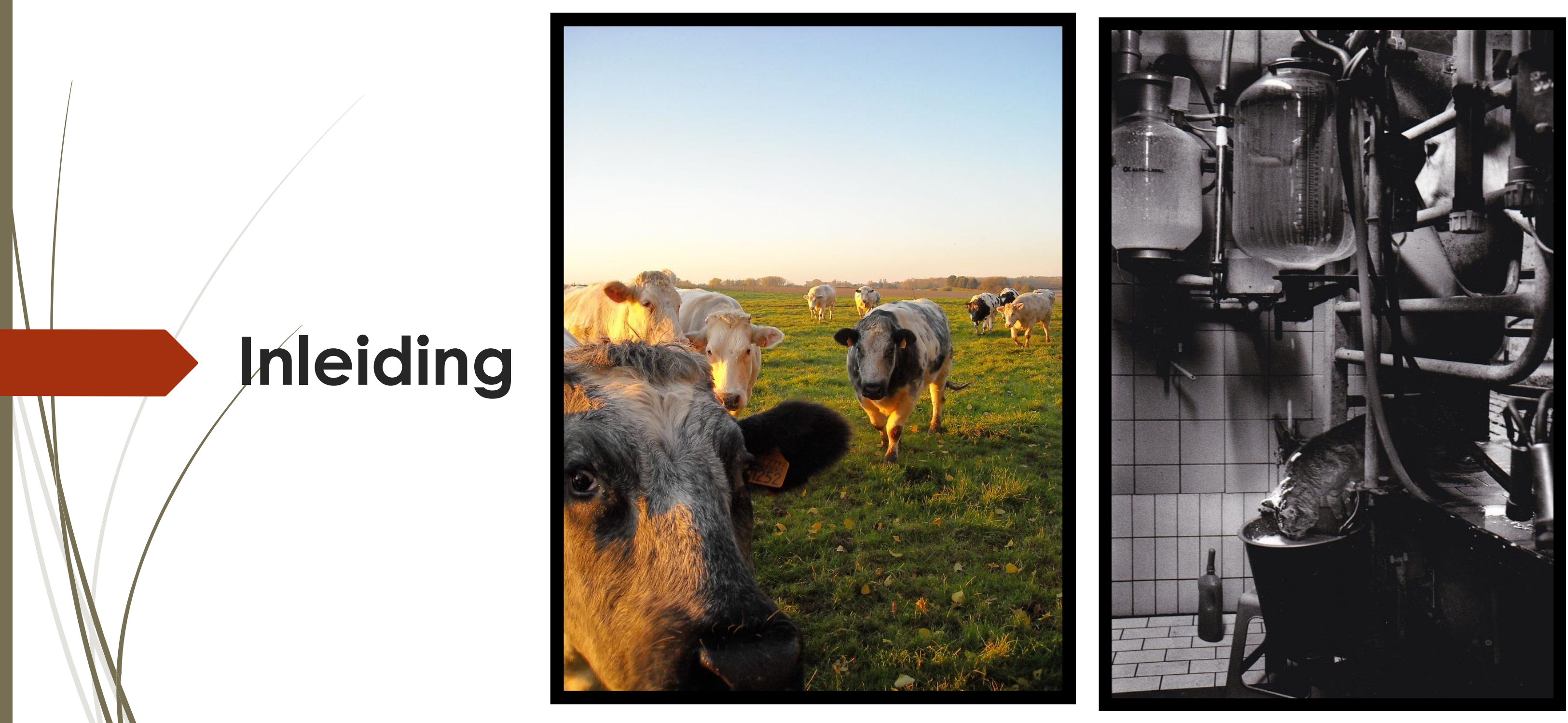




\section{Inleiding}

- Doel = jullie MENING te weten komen

- Geen juiste en zeker geen foute antwoorden!

- Hoe meer, hoe liever!

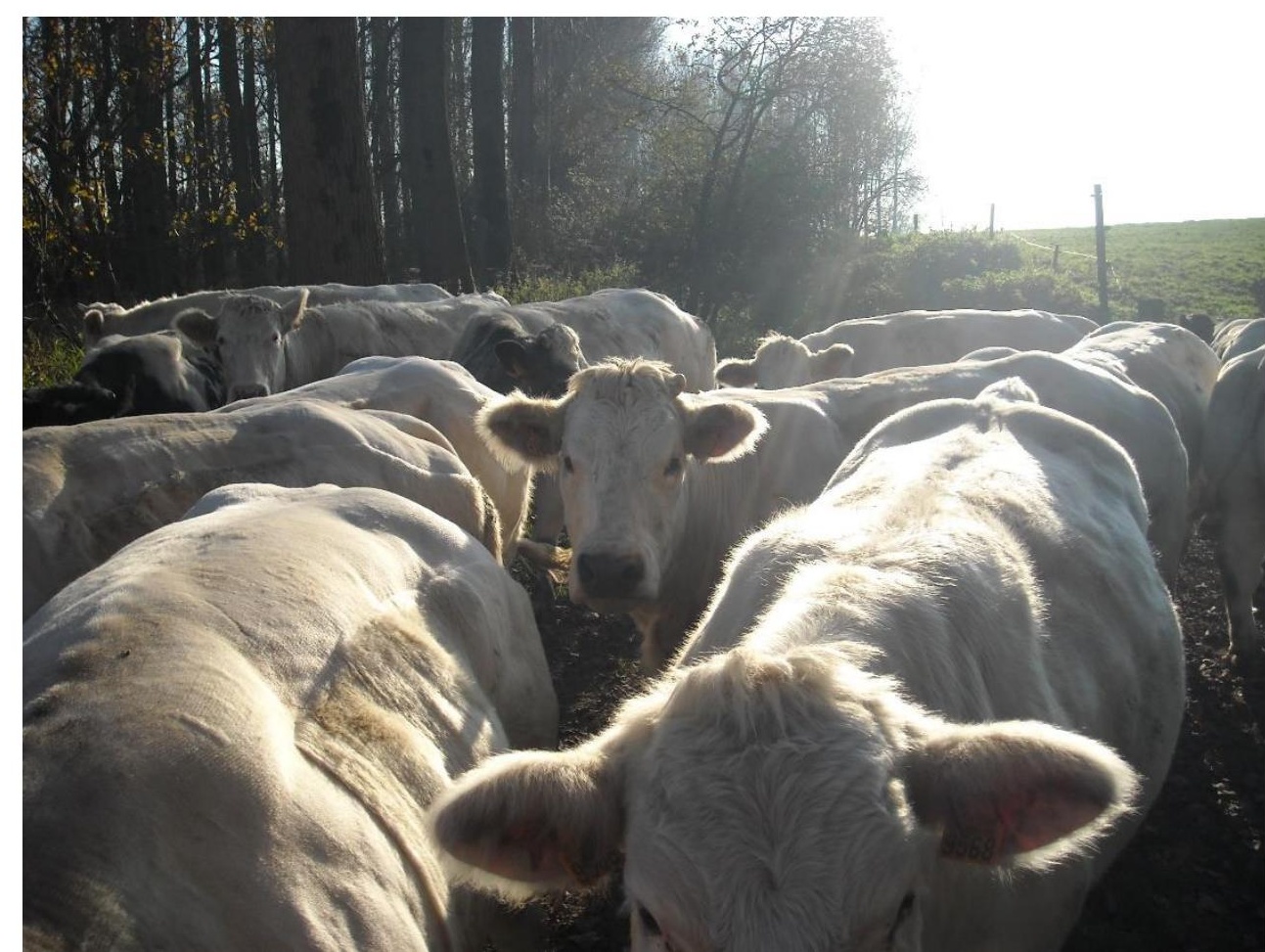




\section{Inleiding}

- Definitie van bioveiligheid? Voorbeelden? 


\section{Inleiding}

- Bioveiligheid = niets nieuws!

maatregelen om te verhinderen dat ziekten van buiten het bedrijf binnenkomen (= externe bioveiligheid)

en om te voorkomen dat ziekten die al aanwezig zijn zich verder zouden verspreiden binnen het bedrijf (= interne bioveiligheid).

- Voorbeelden:

- Handen wassen

- Isolatie van zieke dieren

- Geen overbezetting

- Ongedierte bestrijden

- Geen dieren aankopen, aangekochte dieren in quarantaine - ...

- Biest en vaccinaties? 


\section{y}

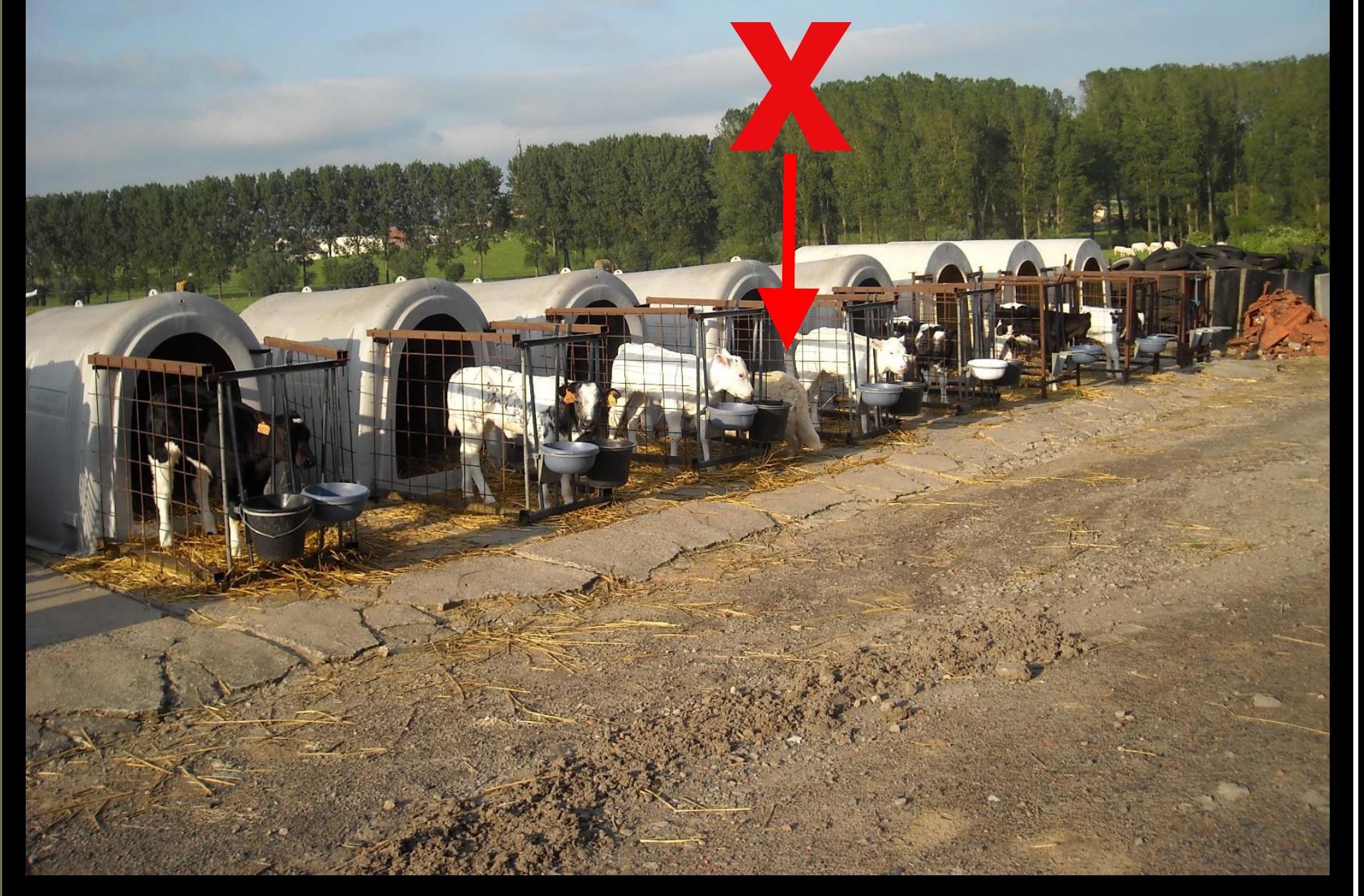




\section{Inleiding}

- Vragen??? 
1) Hoe staat $u$ tegenover "bioveiligheid" en vooral waarom? 
2) Levert bioveiligheid voordelen op voor de dieren / de veehouder / ...?

Zijn er nadelen? 
3) Welke ziekte die aanwezig is op uw bedrijf vindt $u$ het belangrijkst?

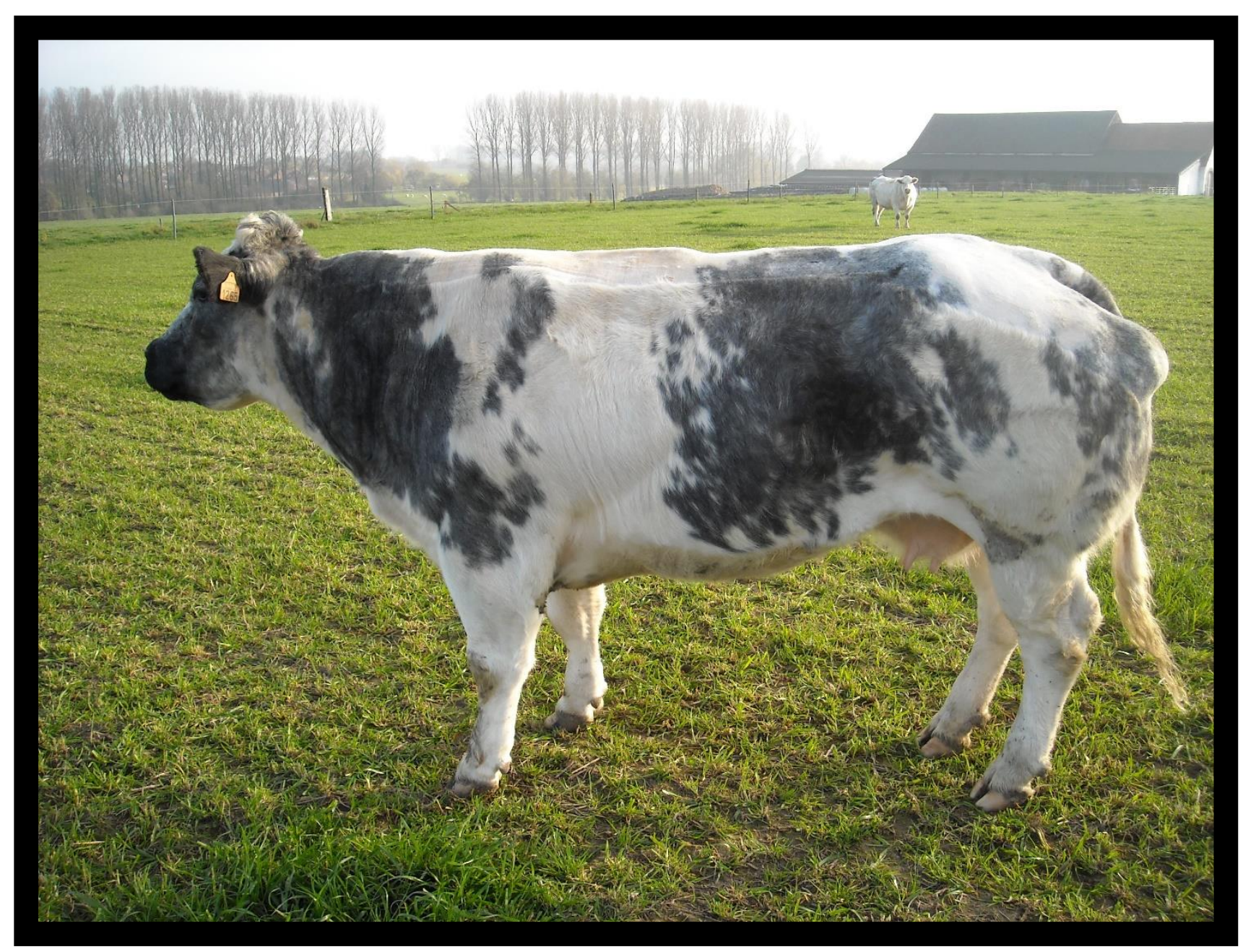




\section{4) Kunnen bioveiligheidsmaatregelen helpen om deze ziekte aan te pakken (minder frequent ziek, minder erg ziek)?}




\section{Opmerking!}

Het doel van bioveiligheid is meerdere ziekten tegelijkertijd aan te pakken! 
5) Uit onderzoek blijkt dat veehouders een gesloten bedrijf behouden (dus geen dieren aankopen) en het testen van aangekochte dieren zeer belangrijk vinden.

MAAR! in de praktijk wordt er zeer weinig aandacht aan deze maatregelen besteed.

Waarom?

Wat houdt deze veehouders tegen? 
Maar nog belangrijker is...

QUARANTAINE

Wat is een goede quarantaine? 


\section{6) Slechts $12 \%$ van de Belgische veehouders plaatst aangekocht vee in quarantaine voor 3 weken.}




\section{Quarantaine is...}

- Klinisch gezonde dieren afzonderen, direct én indirect contact vermijden

- Doel: zowel het nieuw aangekochte dier als de andere dieren beschermen

- Aparte stal / aparte box in stal / aparte weide

- Specifiek materiaal

- Hoe lang???

- 2w/3w/4w/tot de vitslag van het labo-onderzoek bekend is?

- Ondertussen: labo-onderzoek en vaccinaties 
Plaatst $u$ aangekochte dieren in quarantaine? Waarom of waarom niet? 
7) Op de meerderheid van de Belgische rundveebedrijven zijn bedrijfseigen kledij (overall) en laarzen aanwezig voor bezoekers zoals de dierenarts, veehandelaars,... . Toch worden deze zelden gebruikt... 
8) Eén van de meest 'vergeten' regels = werk van jong naar oud, van gezond naar ziek...

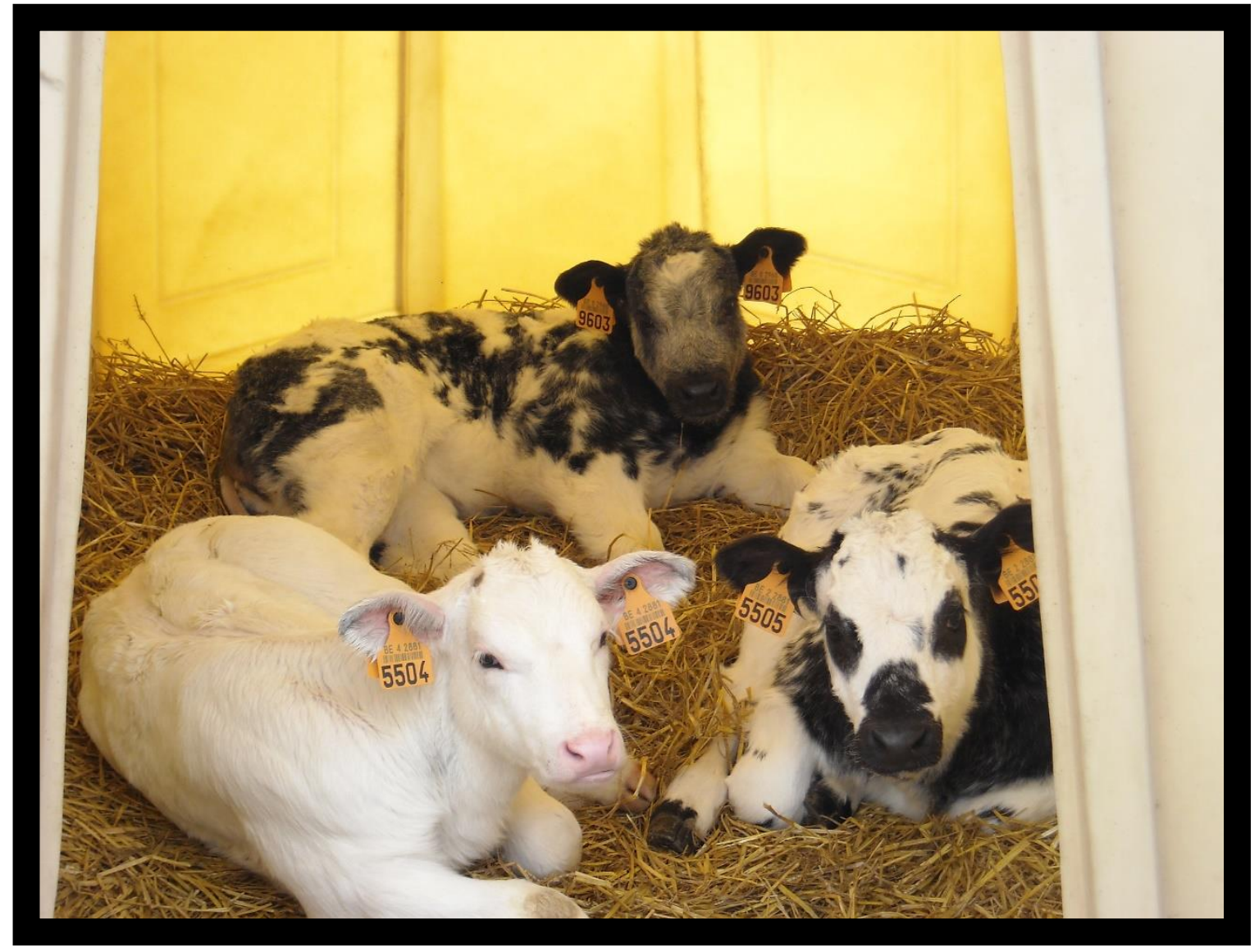


9) Welke mogelijkheden ziet $u$ om de bioveiligheid (algemeen/maatregel X) in de praktijk te verbeteren?

Hoe kunnen veehouders gestimuleerd worden om de bioveiligheid op hun eigen bedrijf te verbeteren? 


\section{EXTRA}

10) Wie zou er moeten meewerken aan de bioveiligheid op uw bedrijf?

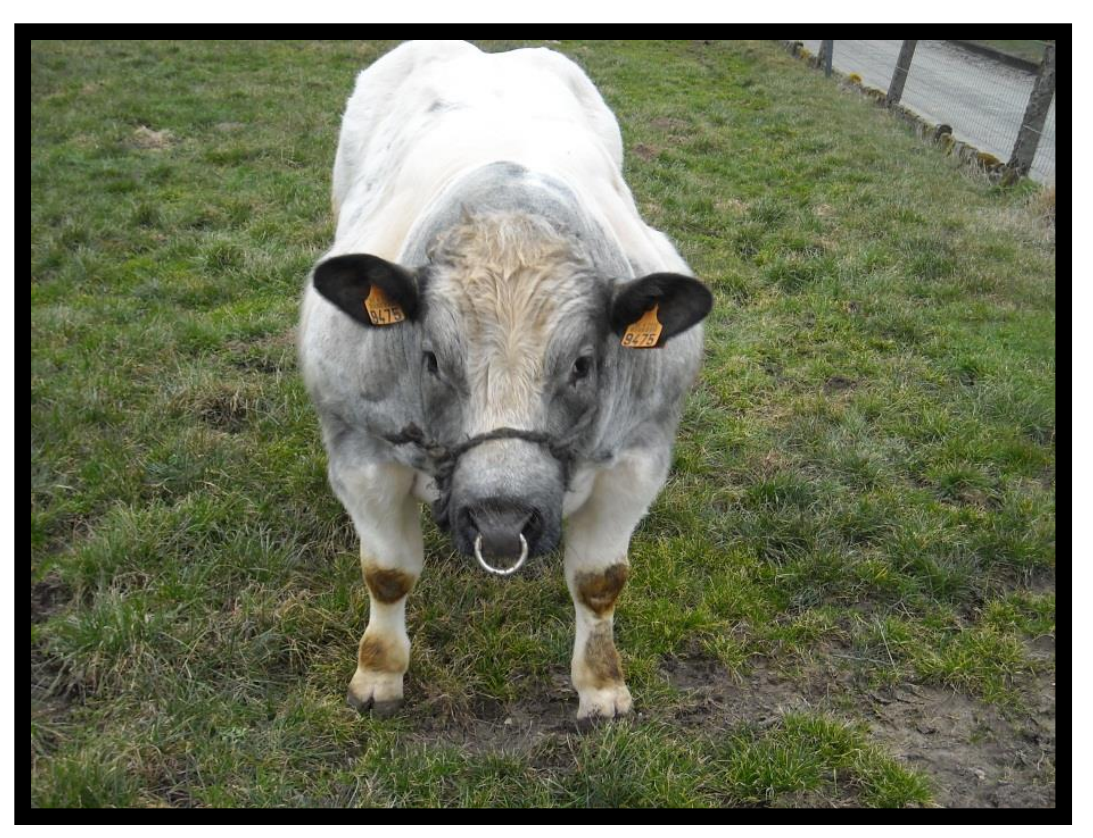




\section{EXTRA}

11) Welke argumenten halen personen die niet willen meewerken aan?

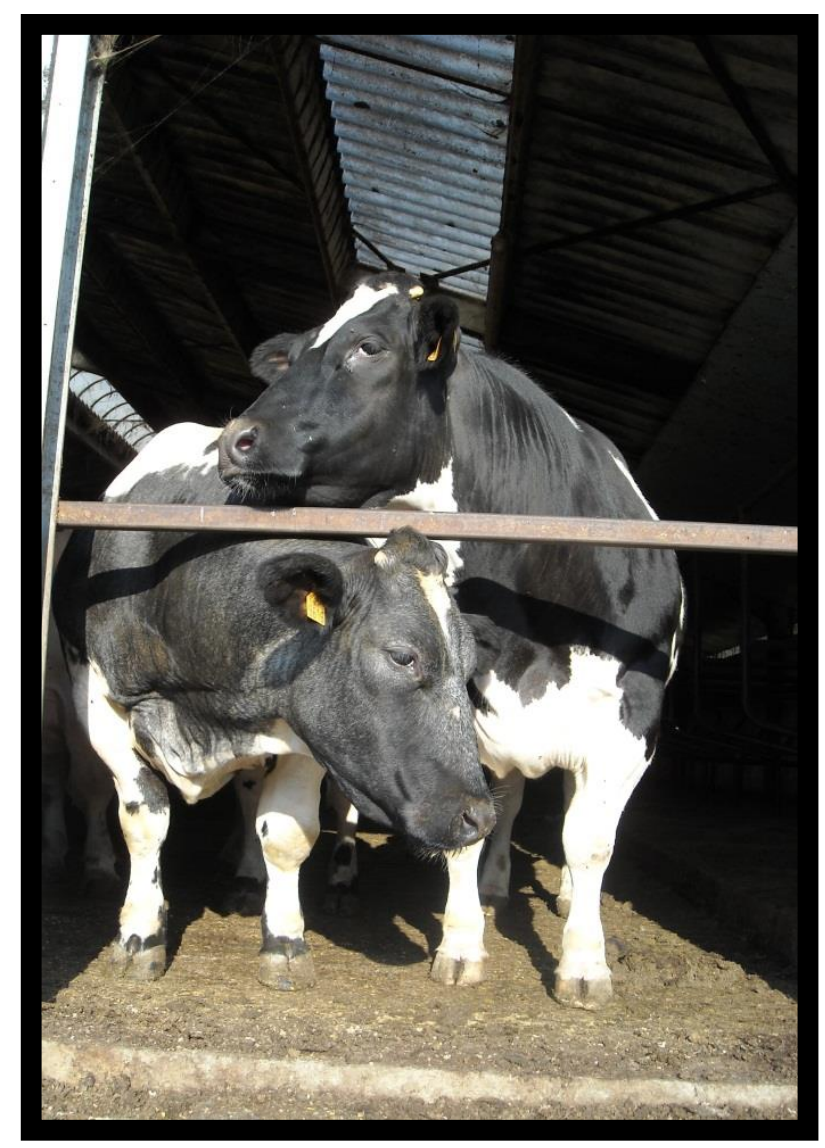




\section{EXTRA}

12) Zeer frequent hebben koeien op de weide de mogelijkheid tot neusneuscontact met "buurkoeien" over/doorheen de omheining. Waarom wordt hieraan geen aandacht besteed? 


\section{EXTRA}

13) Vaak wordt materiaal (veetransport bijvoorbeeld) vitgeleend aan andere veehouders.

Wordt er dan rekening gehouden met de gezondheidsstatus van die veehouders? Zijn deze materialen gereinigd/ontsmet wanneer ze teruggebracht worden? Worden deze nog gereinigd op het bedrijf? 


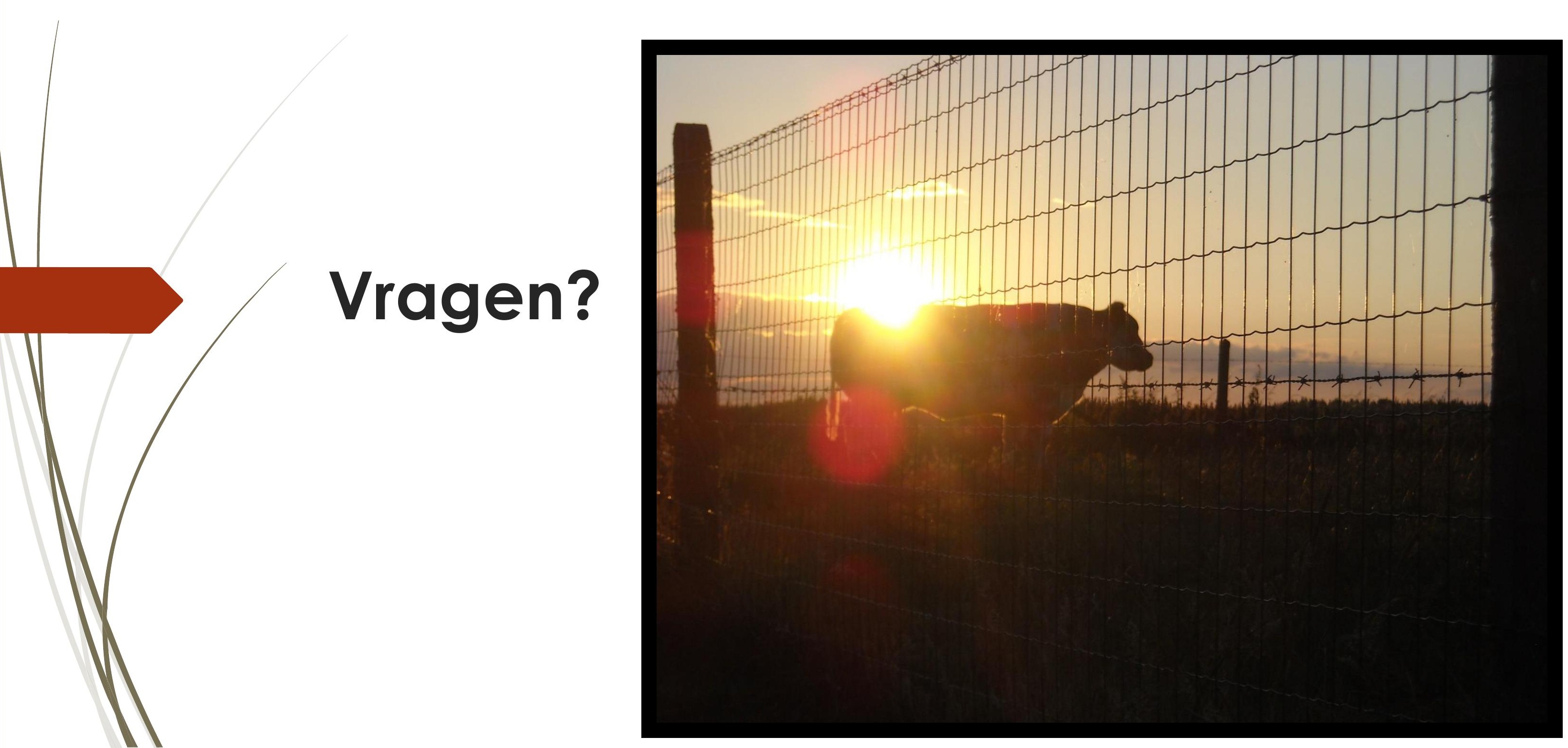




\section{Héél erg bedankt!}

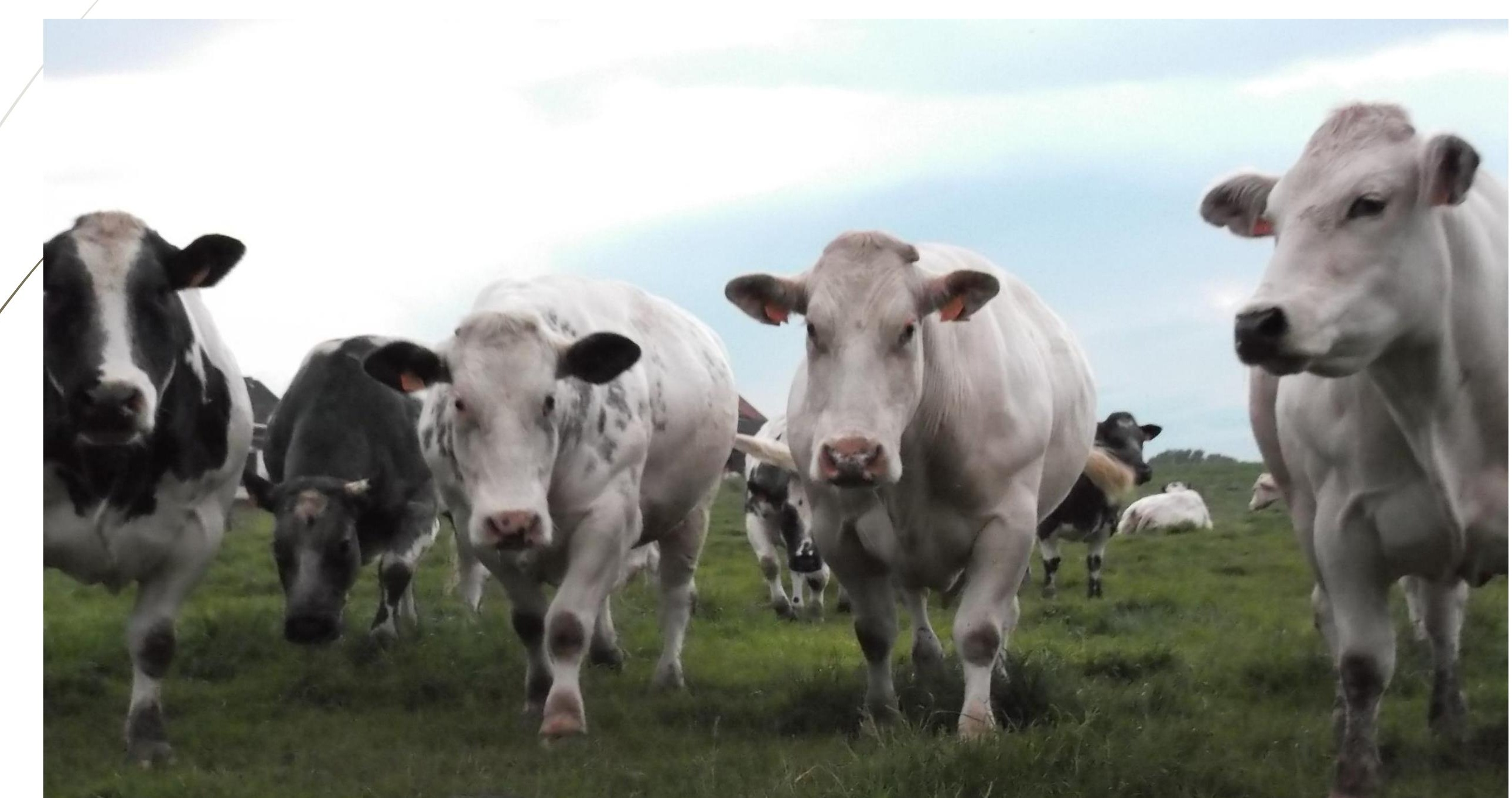

